\title{
Qualitative Study of Social Support for Occupational Safety and Health in the Informal Sector of Limestone Processing in Gunungkidul, Indonesia
}

\author{
Sukismanto Sukismanto ${ }^{1}$, Hartono Hartono ${ }^{2}$, Sumardiyono Sumardiyono ${ }^{3}$, \\ Tri Rejeki Andayani ${ }^{4}$ \\ \{ sukis@ respati.ac.id ${ }^{1}$, hartono65@staff.uns.ac.id ${ }^{2}$, sumardiyono@staff.uns.ac.id $\left.^{3}\right\}$ \\ Doctotral Program in Public Health, Universitas Sebelas Maret, Surakarta, Indonesia ${ }^{1}$ \\ Universitas Respati, Yogyakarta, Yogyakarta, Indonesia ${ }^{1}$ \\ Department of Physiology, Faculty of Medicine, Universitas Sebelas Maret, Surakarta, Indonesia ${ }^{2}$ \\ Department of Public Health, Faculty of Medicine, Universitas Sebelas Maret, Surakarta, Indonesia ${ }^{3}$
}

\begin{abstract}
Law enforcement, commitment, leadership and monitoring of behavior are factors in the implementation of Occupational Safety and Health (OSH). Social environmental factor of workers is a potential that needs to be identified for improving the implementation of OSH. The qualitative research with respondents were executors of OSH programs, community leaders and workers. Data were collected through in-depth interviews. Data analysis was carried out using factors that influence occupational health behavior with the Lawrence theory approach. The results that the predisposing factor for knowledge workers are limited. Availability of personal protective equipment is an enabling factor. Strengthening factors, namely the coaching support from Puskesmas, the activeness of health cadres. Limited understanding of implementation, absence of work monitoring and continous appeals and social support are obstacles to the implementation of OSH. Social support who have the potential to optimize the implementation of providing information, motivation and monitoring the implementation of $\mathrm{OSH}$.
\end{abstract}

Keywords: Occupational safety and health, limestone processing, Gunungkidul.

\section{Introduction}

Occupational safety and health (OSH) in every workplace is very important to increase work productivity and product quality. The implementation of rules and inspection on a hazard is a success factor in fulfilling the safety and health of workers (1). The results of Bluff's research state that providing information, training, instruction and supervision is effective in improving the implementation of work in a healthy and safe manner for small and medium industries (2). Aburumman added that success in work safety is a commitment to safety, leadership and behavior monitoring (3). This factor has been implemented in formal sector jobs, but for the informal sector it cannot be implemented.

Informal sector workplaces have fundamental differences such as organization, management and nature of work (4). Informal sector workplaces do not have certain requirements to be able to carry out work in that work area. Awareness, willingness and technical ability are factors that underlie informal sector work so that the heterogeneity of age, sex, education level, work ability and motivation varies widely. The successful 
implementation of OSH requires the role of people who are able to act as information givers, trainers, motivators, monitoring and active supervision. According to the ecological theory of Urie Bronfenbrenner that there are subsystems that can affect a person's development, the subsystem of the micro-systems says that environmental factors such as colleagues and family can influence a person (5). Referring to this theory, the microsystem of workers, namely family, community leaders, neighbors, colleagues can play a role in efforts to improve OSH for workers as social support. Some research results show that social support has a role to increase motivation and positive attention, experience information and friendship (6), another role for peers is to provide information on limited human resources, comfortable interaction and supervision (7) and proximity to workers can provide more effective information experience (8).

In Indonesia, the number of informal sector workers is $56.50 \%$ (9), while in Daerah Istimewa Yogyakarta (DIY) the number of informal sector workers is $51.59 \%$ more than formal sector jobs (10). Gunungkidul Regency is one of the Provinces in DIY with conditions of clusters of karst mountainous areas, so the community uses it as a potential source of income by processing limestone, so the main risk of danger to workers is exposure to limestone dust. Although there is no data on the results of workers' health examinations, if seen from the number of diseases associated with the respiratory tract, acute nasopharyngitis is in first place $(8.49 \%)$, acute upper respiratory infection is number $3(4.44 \%)(11)$. The government through the Ministry of Health of the Republic of Indonesia has mandated the establishment of an Occupational Health Effort (Pos UKK) as a place for the implementation of occupational health for the community whose guidance is carried out by the Community Health Center (Puskesmas), although the implementation of occupational health by Pos UKK has not been optimally implemented (12).

Based on the description above, to the knowledge of the researcher, there is no research on the needs of workers in the role of social support to increase the implementation of OSH to the knowledge of the researcher, so main of this study is how the workers' needs for social support for limestone processing workers in improving the implementation of $\mathrm{OSH}$ in Gunungkidul Regency, DIY Province.

\section{Methods}

The research was conducted in Gunungkidul Regency, DIY, Indonesia, which has the character of a limestone mountain area, so that the community uses this potential as a livelihood as a limestone processor. Limestone processing workplaces are carried out in groups of 5 to 20 workers. The workplace is owned by a business owner or joint property that is done by neighbors or family of the business owner. The workplace is one or not far from the local residents' settlements. In Indonesia, the implementation / coaching of occupational health in the informal sector is the responsibility of Puskesmas in each sub-district with the establishment of Pos UKK for similar work groups. The function of the Puskesmas is to provide guidance to the Pos UKK.

\subsection{Data analysis}

Respondent interview data were recorded during the interview process and then compiled into an interview transcript. The step of implementing data analysis begins with the researcher 
rereading the interview transcript, moving it into a table / matrix to map the results of the interview and making it easier to see the relationship between the analysis categories, the matrix containing the respondents' answers which are grouped into supporting and inhibiting factors for implementing OSH then identified according to predisposing factors, driving and enabling questions and questions according to the objectives and research concepts of several informants.

\subsection{Reliability}

Ensuring reliable data to be analyzed by data collection using triangulation of respondents from various variations in source positions. Research informants were 1) limestone processing workers, 2) health cadres, 3) hamlet heads and 4) executors of occupational health programs at Puskesmas. Respondent interview data were recorded during the interview process and then compiled into an interview.

\subsection{Ethical clearance}

This study has obtained ethical feasibility from the health research ethics committee of the Fakultas kedokteran, Universitas Sebelas Maret No. 176 / UN27.06.6.1 / KEPK / EC / 2020.

\section{Result}

The work process of limestone processing begins with sorting the rocks that will be put into a grinding machine, followed by grinding limestone into lime powder, milled lime powder is packed into sacks with volumes according to the order ranging from $5 \mathrm{~kg}$ to $50 \mathrm{~kg}$. The process has the main potential hazards of exposure to lime dust, ergonomics of work, falling / getting caught in limestone, being hit by a limestone crusher and noise from grinding machines. The work place of limestone processing by the community is known as a factory. Each factory has a minimum of 5 people who carry out joint work activities. Working hours start from $7 \mathrm{AM}$ to $8 \mathrm{AM}$ until $12 \mathrm{PM}$, then $12 \mathrm{PM}$ to $1 \mathrm{PM}$ is a break time. Work is resumed from $1 \mathrm{PM}$ to $4 \mathrm{PM}$ with a maximum limit of $6 \mathrm{PM}$ or just before the evening prayer time. During the break, the workers return to their respective homes.

Workers are people who live around the factory, the ages of the workers are mostly adults and at the time of observation, there were child workers who helped because they were not in school and learning from home during the Covid-19 pandemic conditions. The workers only know that the risk factors for the hazards that exist are only lime dust, while the others are not a risk. The attitude of the worker agrees to carry out occupational health according to the understanding he knows, occupational health behavior is still not fully implementing occupational health.

The health office provides a policy so that Puskesmas form Pos UKK for people who have similar jobs, Puskesmas provide guidance to the implementation of Pos UKK through occupational health programs. Pos UKK has a health cadres whose job is to carry out monitoring of workers' health and health education to workers. The existing community organizations are meetings of the Rukun Tangga (RT), Hamlet and also meetings such as Posyandu. The management of Pos UKK is carried out by health cadres who are the driving 
force for Posyandu / Posbindu activities. During the Covid-19 pandemic the meetings were not actively run.

Table 1. The process of analyzing qualitative data from the topic to coding the results of the respondents in-depth interviews

\begin{tabular}{|c|c|c|c|}
\hline Topic & Meaning Unit & Condensed MU & Code \\
\hline $\begin{array}{l}\text { What } \\
\text { occupational } \\
\text { health programs } \\
\text { are run by the } \\
\text { Puskesmas }\end{array}$ & $\begin{array}{l}\text { - The health office asks each puskesmas to } \\
\text { form a Pos UKK and asks for reports of } \\
\text { accidents / illnesses, the Puskesmas } \\
\text { provides guidance for a pos UKK, OSH } \\
\text { health education, monev once a year, } \\
\text { coaching once a month, when the } \\
\text { puskesmas performs medication } \\
\text { (Puskesmas) } \\
\text { - The agency recommends the existence } \\
\text { of a pos UKK activity at the Puskesmas, } \\
\text { but it has not been established because } \\
\text { of the lack of community response. } \\
\text { (Puskesmas) } \\
\text { - Implementation of health checks, health } \\
\text { promotion of Personal Parotective } \\
\text { Equipment (PPE) use. (health cadres) } \\
\text { - Carry out assistance in health } \\
\text { examinations. } \\
\text { - Advise when working to use a mask to } \\
\text { protect yourself. } \\
\text { - Conducting tension health checks, } \\
\text { giving masks, health education while } \\
\text { working using personal protection. }\end{array}$ & $\begin{array}{l}\text { - Socialization of } \\
\text { occupational } \\
\text { health } \\
\text { programs } \\
\text { - Establishment } \\
\text { of the Pos UKK } \\
\text { - Provide } \\
\text { assistance to } \\
\text { health cadres }\end{array}$ & $\begin{array}{l}\text { Policy support } \\
\text { from the health } \\
\text { office, } \\
\text { puskesmas }\end{array}$ \\
\hline $\begin{array}{l}\text { What is the role } \\
\text { of the health } \\
\text { center health } \\
\text { worker }\end{array}$ & $\begin{array}{l}\text { - Side counseling in posbindu activities. } \\
\text { - Disseminate health programs for } \\
\text { workers to wear masks, gather dukuhs } \\
\text { and cadres to improve factory } \\
\text { performance to use masks. } \\
\text { - Assistance of Pos UKK cadres and } \\
\text { supervision of occupational health } \\
\text { activities }\end{array}$ & $\begin{array}{ll}\text { - Providing } & \\
\text { health } & \\
\text { education } & \\
\text { - Carry } & \text { out } \\
\text { coaching } & \text { for } \\
\text { cadres } & \end{array}$ & $\begin{array}{l}\text { There is support } \\
\text { from puskesmas } \\
\text { health workers }\end{array}$ \\
\hline $\begin{array}{l}\text { What is the role } \\
\text { of health cadres }\end{array}$ & $\begin{array}{l}\text { - Move workers. } \\
\text { - Referring if there is an accident, } \\
\text { conducting medical examinations, } \\
\text { providing health education, mobilizing } \\
\text { workers. } \\
\text { - Tension health checks, health } \\
\text { information }\end{array}$ & $\begin{array}{l}\text { - Coordinating } \\
\text { workers and the } \\
\text { community } \\
\text { - Limited health } \\
\text { checks } \\
\text { - Referring to } \\
\text { work accidents }\end{array}$ & $\begin{array}{l}\text { There is support } \\
\text { for the role of } \\
\text { health cadres }\end{array}$ \\
\hline $\begin{array}{l}\text { What is the role } \\
\text { of the work } \\
\text { owner }\end{array}$ & $\begin{array}{l}\text { - Helping the work process, providing } \\
\text { PPE masks, suggesting using masks. } \\
\text { - Helping work during high orders by } \\
\text { inserting limestone into the grinding } \\
\text { machine }\end{array}$ & $\begin{array}{l}\text { - Provide PPE } \\
\text { for workers } \\
\text { - Providing } \\
\text { health } \\
\text { education } \\
\end{array}$ & $\begin{array}{l}\text { There is support } \\
\text { from the work } \\
\text { owner }\end{array}$ \\
\hline $\begin{array}{l}\text { What is the role } \\
\text { of community } \\
\text { leaders }\end{array}$ & $\begin{array}{l}\text { - Provide support for the implementation } \\
\text { of activities for health cadres and } \\
\text { workers, provide socialization support }\end{array}$ & $\begin{array}{l}\text { - Supports the } \\
\text { implementation } \\
\text { of activities }\end{array}$ & $\begin{array}{l}\text { There is support } \\
\text { from community } \\
\text { leaders }\end{array}$ \\
\hline
\end{tabular}




\begin{tabular}{|c|c|c|c|}
\hline & $\begin{array}{l}\text { from the puskesmas. } \\
\text { - Facilitating meetings for health outreach } \\
\text { such as PKK, posyandu, etc }\end{array}$ & $\begin{array}{l}\text { - Facilitate } \\
\text { meetings }\end{array}$ & \\
\hline $\begin{array}{l}\text { Do workers } \\
\text { understand } \\
\text { occupational } \\
\text { health }\end{array}$ & $\begin{array}{l}\text { - There is only a small risk of the grinder } \\
\text { being exposed to dust. } \\
\text { - Beaten, falling stones due to working } \\
\text { with stones, wearing a mask so as not to } \\
\text { be exposed to lime dust. } \\
\text { - Don't think it's important to be careful } \\
\text { yourself. } \\
\text { - Understand, interfere with breathing, } \\
\text { irritate the eyes, become irritated, but } \\
\text { sometimes don't use them }\end{array}$ & $\begin{array}{l}\text { - Knowing the } \\
\text { occupational } \\
\text { risks in the } \\
\text { form of dust } \\
\text { exposure } \\
\text { - Not yet fully } \\
\text { understanding } \\
\text { the job risks }\end{array}$ & $\begin{array}{l}\text { Lack of } \\
\text { understanding of } \\
\text { workers about } \\
\text { occupational } \\
\text { risks and the } \\
\text { efforts to } \\
\text { prevent them }\end{array}$ \\
\hline $\begin{array}{l}\text { Are there any } \\
\text { rules that apply } \\
\text { to workers }\end{array}$ & $\begin{array}{l}\text { - Nothing, only working time from } 8 \text { to } \\
16.00 \text { break time from } 12.00-13.00 \\
\text { (Workers), during breaks the workers } \\
\text { return home. } \\
\text { - Working time if you leave a little late, } \\
\text { no problem. } \\
\text { - It's up to the worker how you want to } \\
\text { wear a mask or not, the work owner does } \\
\text { not require it. } \\
\text { - Yes, it is advisable to wear a mask }\end{array}$ & $\begin{array}{l}\text { unwritten rules } \\
\text { regarding } \\
\text { working hours }\end{array}$ & $\begin{array}{l}\text { There is support } \\
\text { for working time } \\
\text { regulations, but } \\
\text { nothing is } \\
\text { specific about } \\
\text { occupational } \\
\text { health }\end{array}$ \\
\hline $\begin{array}{l}\text { Do workers } \\
\text { wear PPE }\end{array}$ & $\begin{array}{l}\text { - Sometimes I wear. } \\
\text { - Workers wear masks. } \\
\text { - Wear a mask if the machine beeps }\end{array}$ & $\begin{array}{l}\text { Some are wearing } \\
\text { masks }\end{array}$ & $\begin{array}{l}\text { Lack } \\
\text { awareness } \\
\text { using PPE }\end{array}$ \\
\hline $\begin{array}{l}\text { Who provides } \\
\text { PPE } \\
\text { procurement }\end{array}$ & $\begin{array}{l}\text { - Work owner. } \\
\text { - Buy it yourself. } \\
\text { - Masks have been provided by the work } \\
\text { owner }\end{array}$ & $\begin{array}{lr}\text { Owners } & \text { of } \\
\text { companies } & \text { and } \\
\text { independent } & \\
\text { workers } & \\
\end{array}$ & $\begin{array}{l}\text { Support from } \\
\text { the work owner } \\
\text { for the provision } \\
\text { of PPE }\end{array}$ \\
\hline
\end{tabular}

In-depth interviews with several resource persons including 6 workers, community leaders consisting of the head of the village community and 4 health cadres, 3 people managing the occupational health program at the Puskesmas. The results of the study found various supporting and inhibiting factors in the implementation of $\mathrm{OSH}$ in limestone processors in Gunungkidul. Supporting factors include 1. Program support and mentoring from Puskesmas, 2. Active motivation from health cadres, 3. Availability of PPE facilities from business owners, 4. Support for meeting facilities from community leaders / hamlets, 5. Support from the community's social environment. Factors that make it an obstacle include 1. Knowledge and understanding of risk factors for hazards that are still low, 2. Lack of selfmotivation to carry out occupational health, 3 . Lack of monitoring from business owners and other social support.

\subsection{Inhibiting factors for the implementation of OSH}

The knowledge and understanding of limestone processing workers on the risk factors of hazards is a fundamental factor that is an inhibiting factor in the implementation of OSH. The workers consider that the occupational health risk factor is only lime dust and even the fall of the rock is not a big problem. "... yes, the risk is working like this to chalk dust, if a hit or falling of a rock is normal and not a serious problem .." (worker). Workers' lack of motivation in using PPE such as masks, headgear, gloves because they think that using PPE is 
uncomfortable and disturbs in work activities, thereby reducing the number of work results. "... if the machine is running, use a mask, but sometimes I forget because after drinking, smoking so I have a mask, but I put it ..." (worker).

Lack of motivation in implementing OSH from business owners and other social circles so that workers do not implement efforts to prevent existing work risk factors. "... the work owner has provided masks for workers and to use them, but it's up to the workers to wear them or not ..." (worker), "... the work owners don't wear them, so workers don't wear masks at work either ... (Health cadres). "... if the owner of the work doesn't require it, it's up to you to use it or not ..." (worker).

\subsection{Supporting factors for the implementation of OSH}

Government programs for the implementation of occupational health in the informal sector are implemented through the Puskesmas program. Puskesmas that actively carry out coaching become a supporting factor for workers in implementing OSH. "... there is a provision of medical examination tools from the Puskesmas such as scales, tensimeters and assistance during medical examinations to workers ..." (health cadres). "... yes, it was previously told to wear masks, shoes, gloves from the Puskesmas and have their health checked there (hamlet hall) ..." (worker).

Community leaders provide support by providing facilities for the hamlet hall as the location for the Pos UKK or village and RT level meetings for the implementation of activities and socialization of efforts to improve OSH. "... the head of the hamlet fully supports the activities of the cadre women to carry out activities at the hamlet hall or other meetings for health outreach ...". (hamlet).

Health cadres of the Pos UKK are active in providing occupational health services in accordance with the directions given by the Puskesmas health workers, namely tension checks, weighing and referring workers if there are health problems or work accidents to the Puskesmas which is responsible for their area. "... yes, before Covid, there was a meeting for weighing and measuring tension, sometimes I had to go around to workers to do that and report to the Puskesmas, I was taught to also refer sick workers to the Puskesmas". (health cadres).

Availability of masks as personal protective equipment. Business owners providing and giving masks to workers are a facilitation provided so that workers can use them as personal protective equipment from the risk of the dangers of lime dust. "... yes (masks) have been provided, if they can't be used, they can take them again, they have been provided ..." (worker)

The social conditions of the community that support the implementation of work in the community because the location of the work is integrated with the residential area. There are rules but not written that already exist in the community, such as working time which starts in the morning around 07.00 to $08.00 \mathrm{WIB}$ until $12.00 \mathrm{WIB}$ before midday prayer time and lunch time. Work is resumed from 13.00 to $16.00 \mathrm{WIB}$, this time is flexible according to factory production conditions. The working time limit for production machines must be turned off just before the maghrib call to prayer until the morning, besides that if a resident is having an event such as a wedding or someone dies, some of the areas closest to the location will not carry out the production process. "... yes, the working time is as agreed upon, starting between 07.00 or 08.00 to 12.00 then they go home and then resume at 13.00 until it finishes at approximately 16.00, which means that in the afternoon and evening, you cannot turn on the milling machine, or if you are currently someone died ... "(hamlet) 
The implementation of OSH in limestone processors has the support of resources from the government, work owners and the community. Government support that has been provided, such as assistance to health cadres training, and the formation of a Pos UKK organization as the spearhead in the implementation of occupational health. support from business owners including the provision of personal protective equipment such as masks, providing food and drink at workplaces. Support from the community with shared ethics in the production process paying attention to work and rest time according to unwritten ethics in the community and mutually agreed upon, facilitation from the hamlet to carry out OSH-related activities in hamlet events as well as the active health cadres of the Pos UKK to serve workers.

\section{Discussion}

In general, the factors of behavior change in health include intrapersonal factors, interpersonal theory and community. Intrapersonal factors such as cognitive domains, past experiences and motivations. Interpersonal combines social structure factors and individual characteristics. According to the theory developed by Lawrence Green and Kreuter that the problem analysis begins with a social, administrative and policy assessment, namely the Precede step. Precede includes analysis of Predisposing, Reinforcing, Enabling factors (13).

Safety behavior and attitudes are influenced by a person's knowledge of safety. This is in accordance with the results of the research by Marquardt Hoebel (2020) that there is a significant change in the elements of safety culture after participating in training (14), so that limestone processing workers' knowledge about occupational health and safety is one of the inhibiting factors in the implementation of occupational health for limestone processors in Gunungkidul. Education is a factor related to the level of public knowledge, education is very important in the implementation of occupational health even though it is not the main one, it is necessary to look at cultural structures that can describe the attitudes of society and individuals towards new social norms to focus attention on health behavior (15), so that in stone processing lime which is a rural community needs to involve social structures that can support the implementation of occupational health. The structure of the community in the limestone processing area that the workplace is in a residential area and the workers are mostly local people. The community is led by a head of a village called dukuh. The structure of the community that promotes occupational safety and health is a Pos UKK organization which is managed by trained health cadres. The function of health cadres as information providers about occupational health is the result of research by Caffaro et al (2018) that training can make a major contribution to the achievement of effective OSH information, but this review shows that more evidence is needed to guide the development of effective training activities (16).

The finding of inhibiting factors in the implementation of work safety and health of limestone processing is the lack of information, monitoring and motivation in the implementation of occupational safety and health from the work owner and other social support in the workplace and in the community. according to Aburumman (2019) the most successful interventions are related to the importance of safety, leadership style and behavior monitoring (3). Lack of supervisor support increases the likelihood of physical injury in the workplace. The risk of physical injury is 3.5 times higher among workers who are vulnerable and lack supervisory support (17). Limestone processing work is an informal sector job so that there is no formal relationship between workers and employers but based on kinship so that 
there are no written rules that bind formally to be obeyed together, especially regulations related to occupational safety and health. This condition is not in line with the opinion of the research results of Andersen et al (2019) that increasing the implementation of occupational safety and health is the enforcement of legal regulations and the implementation of inspections on a hazard and the fulfillment of workers' safety and health (1).

From the identification of inhibiting and supporting factors for the implementation of work health in limestone processing, there is a social condition that can be optimized in the role of improving occupational health with the function of providing information, motivation and monitoring of the implementation of occupational health at work. Potential workers who come from the community where they live, take time off to return home so that the intensity that is often encountered for workers is family and co-workers. so that the social potential of the community can be used as a social support group. Social support that can play a role such as family and co-workers. Family support acts as a provider of emotional support and instrumentation support that can increase positive values in work outcomes (18). The results of research by Bush et al (2014) on the evaluation of a pilot program for forest immigrant workers health counseling in southern Latin states that working group health educators can increase work capacity, improve leadership and community access to information and health and safety resources. Peer support can improve positive motivation and attention, experiential information and friendship (6). Regarding social support, it is also in line with the theory of Urie Bronfenbrenner that in the individual experience, it is the driving force of behavior, in this case, the practice of occupational health, where the micro-system sub-system is the closest personal environment to workers, namely family, co-workers, and neighboring communities. So that the support of family and coworkers can influence worker behavior. The relationship between microsystems can influence each other into a larger sub-system, namely the mesosystem. In a more complex sub-system, namely the ecosystem, even though it does not interact directly with workers, it can affect workers' behavior, for example, the involvement of information obtained by family, coworkers and other social communities can affect the behavior of workers (5). The role of social support can increase motivation which will increase the level of participation in the implementation of OSH (19). Based on the above discussion, so that the implementation of OSH in informal sector work can be improved, further research can be carried out to optimize the role of social support, namely family support and peer support.

\subsection{Research limitations}

Triangulation is done by triangulating sources of informants, triangulation of data sources such as documentation of the results of recording cannot be done because the organization is informal so that the data cannot be shown from the data source. The results of interviews from various information sources based on roles and levels in the community can be a reliable data source according to the existing conditions of limestone processing workers.

\section{Conclusion}

Supporting factors for the implementation of OSH are the assistance policy from the Puskesmas, the provision of PPE facilities in the form of masks by the work owner, the active role of health cadres of the Pos UKK and the support of local community leaders. The 
inhibiting factors for the implementation of OSH are limited knowledge, lack of motivation from both workers and the working community, lack of monitoring from business owners. Further research suggested is to develop the role of family and peer support to increase knowledge, attitudes and practices of OSH in limestone processors.

\section{References}

[1] Andersen JH, Malmros P, Ebbehoej NE, Flachs EM, Bengtsen E, Bonde JP. Systematic literature review on the effects of occupational safety and health $(\mathrm{OSH})$ interventions at the workplace. Scand J Work Environ Heal. 2019;45(2):103-13.

[2] [2] Bluff E. How SMEs respond to legal requirements to provide information, training, instruction and supervision to workers about work health and safety matters. Saf Sci [Internet]. 2019;116(April 2018):45-57. Available from: https://doi.org/10.1016/j.ssci.2019.02.036

[3] [3] Aburumman M, Newnam S, Fildes B. Evaluating the effectiveness of workplace interventions in improving safety culture: A systematic review. Saf Sci [Internet]. 2019;115(December 2017):376-92. Available from: https://doi.org/10.1016/j.ssci.2019.02.027

[4] [4] BPN. Peran Sektor Informal sebagai Katup Pengaman Masalah Ketenagaankerjaan [Internet]. Badan Perencanaan Pembangunan Nasional. Jakarta Indonesia; 2009. 1-99 p. Available from: https://www.bappenas.go.id/files/3513/5027/3734/kajian-peran-sektorinformal2010090310304327490_20110518101103_3050_0.pdf

[5] [5] Bronfenbrenner U. Ecology of the family as a context for human development. Dev Psychol. 1986;22(6):723-42.

[6] [6] Tse S, Mak WWS, Lo IWK, Liu LL, Yuen WWY, Yau S, et al. A one-year longitudinal qualitative study of peer support services in a non-Western context: The perspectives of peer support workers, service users, and co-workers. Psychiatry Res [Internet]. 2017;255(August 2016):27-35. Available from: http://dx.doi.org/10.1016/j.psychres.2017.05.007

[7] [7] Bush DE, Wilmsen C, Sasaki T, Barton-Antonio D, Steege AL, Chang C. Evaluation of a pilot promotora program for Latino forest workers in Southern Oregon. Am J Ind Med. 2014;57(7):78899.

[8] [8] Gagne CA, Finch WL, Myrick KJ, Davis LM. Peer Workers in the Behavioral and Integrated Health Workforce: Opportunities and Future Directions. Am J Prev Med [Internet]. 2018;54(6):S258-66. Available from: http://dx.doi.org/10.1016/j.amepre.2018.03.010

[9] [9] BPS. Keadaan Ketenagakerjaan Indonesia Februari 2020 [Internet]. Berita Resmi Statistik. Jakarta Indonesia: Badan Pusat Statistik; 2020. 1-20 p. Available from: https://www.bps.go.id

[10] [10]BPS DIY. Statistik ketenagakerjaan daerah Istimewa Yogyakarta 2019-2020 [Internet]. Yogyakarta: CV Magna Raharja Tama (Mahata); 2019. Available from: https://yogyakarta.bps.go.id

[11] [11]Dinas Kesehatan Gunungkidul. Profil Kesehatan Kabupaten GunungkidulTahun 2018. D.I Yogyakarta; 2018.

[12] [12] Suwarto S, Aini N, Sukismanto S. Gambaran Pelaksanaan Kesehatan Kerja Sektor Informal Melalui Pos Upaya Kesehatan Kerja (Ukk) Di Daerah Istimewa Yogyakarta. J Formil (Forum Ilmiah) Kesmas Respati. 2020;5(1):36.

[13] [13] Green L, Kreuter. Health program planning: An educational and ecological approach. 4th Editio. New York: McGraw Hill; 2005.

[14] [14] Marquardt N, Hoebel M, Lud D. Safety culture transformation-The impact of training on explicit and implicit safety attitudes. Hum Factors Ergon Manuf. 2020;(April 2020):191-207.

[15] [15] Moradhaseli S, Colosio C, Farhadian H, Abbasi E, Ghofranipour F. Designing an agricultural occupational health behavioral model. J Agric Sci Technol. 2020;22(1):57-66.

[16] [16] Caffaro F, Micheletti Cremasco M, Bagagiolo G, Vigoroso L, Cavallo E. Effectiveness of occupational safety and health training for migrant farmworkers: a scoping review. Public Health [Internet]. 2018;160: 10-7. Available from: https://doi.org/10.1016/j.puhe.2018.03.018 
[17] [17] Yanar B, Lay M, Smith PM. The Interplay Between Supervisor Safety Support and Occupational Health and Safety Vulnerability on Work Injury. Saf Health Work [Internet]. 2019;10(2):172-9. Available from: https://doi.org/10.1016/j.shaw.2018.11.001

[18] [18]Leung YK, Mukerjee J, Thurik R. The role of family support in work-family balance and subjective well-being of SME owners. J Small Bus Manag [Internet]. 2020;58(1):130-63. Available from: https://doi.org/10.1080/00472778.2019.1659675

[19] Hedlund A, Gummesson K, Rydell A, Andersson IM. Safety motivation at work: Evaluation of changes from six interventions. Saf Sci. 2016;82: 155-63. 